\title{
Vitreous base avulsion
}

\author{
Vinod Kumar, Saurabh Damodaran, Anu Sharma
}

Dr Rajendra Prasad, Centre for Ophthalmic Sciences, All India Institute of Medical Sciences, New Delhi, India

\section{Correspondence to} Dr Vinod Kumar, drvinod_agg@yahoo.com

Accepted 13 December 2016

CrossMark

\section{To cite: Kumar $V_{1}$}

Damodaran S, Sharma A.

BMJ Case Rep Published

online: [please include Day

Month Year] doi:10.1136/

bcr-2016-218303

\section{DESCRIPTION}

A man aged 30 years presented with a history of floaters OD following history of blunt trauma with a cricket ball 1 week ago. Unaided visual acuity was 20/20 OU. OS was normal. OD showed vitreous base avulsion from 5 to 9'o clock position in a typical bucket handle appearance. Ultra-wide-field (Optos) imaging with eye steered inferiorly showed vitreous base avulsion (figure 1). Rest of the ocular examination was within normal limits. The patient was reassured and advised regular follow-up.

Vitreous base avulsion is considered to be pathognomonic of ocular blunt trauma. During trauma, there is anteroposterior compression and rapid and profound equatorial expansion. This avulses the vitreous base from the retina and pars plana due to differences in their elasticity. Only a single case has been reported where spontaneous vitreous base avulsion occurred in a patient with neurofibromatosis. $^{1}$ Vitreous base avulsion may be associated

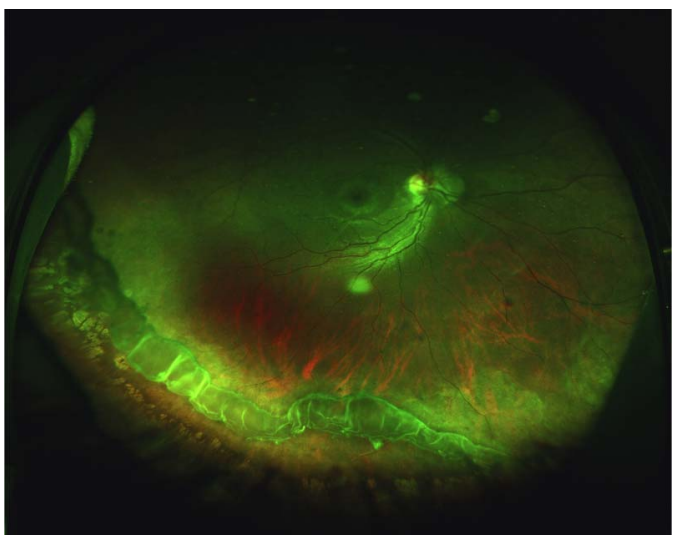

Figure 1 Ultra-wide-field pseudocolour photograph of the right eye showing vitreous base avulsion. with retinal dialysis, retinal tear or vitreous haemorrhage in a high proportion of cases that increases the risk of retinal detachment. A thorough peripheral retinal examination and close follow-up is thus warranted in all patients with vitreous base avulsion.

Being in extreme periphery of the retina, vitreous base avulsion is often not captured using conventional colour imaging. With the availability of ultra-wide-field imaging, it is now possible to image the peripheral retina, which is useful for documentation as well as teaching purposes.

\section{Learning points}

- Vitreous base avulsion, seen in retinal periphery as a bucket handle, is an important sign of previous ocular blunt trauma.

- Ultra-wide-field imaging using Optos imaging system is a useful tool for imaging of peripheral retina.

Contributors All authors contributed towards the manuscript and meet authorship criteria according to ICMJE guidelines. VK is responsible for conduct, conception and design and interpretation of data. SD is responsible for conduct, conception and design and interpretation of data. AS is responsible for conduct and acquisition of data.

Competing interests None declared.

Patient consent Obtained.

Provenance and peer review Not commissioned; externally pee reviewed.

\section{REFERENCE}

1 Desai UR. Spontaneous vitreous base avulsion in a patient with neurofibromatosis. Indian J Ophthalmol 1995;43:33.

\footnotetext{
Copyright 2017 BMJ Publishing Group. All rights reserved. For permission to reuse any of this content visit http://group.bmi.com/group/rights-licensing/permissions.

BMJ Case Report Fellows may re-use this article for personal use and teaching without any further permission.

Become a Fellow of BMJ Case Reports today and you can:

- Submit as many cases as you like

- Enjoy fast sympathetic peer review and rapid publication of accepted articles

- Access all the published articles

- Re-use any of the published material for personal use and teaching without further permission

For information on Institutional Fellowships contact consortiasales@bmjgroup.com

Visit casereports.bmj.com for more articles like this and to become a Fellow
} 